\title{
Analiza poziomu umiędzynarodowienia Zagadnień Naukoznawstwa w kontekście światowych studiów nad nauką i szkolnictwem wyższym
}

DOI: http://dx.doi.org/10.12775/ZN.2019.002

\begin{abstract}
Abstrakt. Celem niniejszego artykułu jest charakterystyka umiędzynarodowienia czasopisma Zagadnienia Naukoznawstwa. Głównym odniesieniem tej analizy jest baza Scopus, która odegrała kluczową rolę w przeprowadzonej przez Ministerstwo Nauki i Szkolnictwa Wyższego kategoryzacji polskich i międzynarodowych czasopism naukowych. Niniejsze opracowanie wykorzystuje pewne elementy wcześniejszych prac autora (Kawalec 2017, 2019). W analizie cytowań czasopisma Zagadnienia Naukoznawstwa zwrócono szczególną uwagę na źródła, które mają wysoką cytowalność w bazie Scopus, a także wyodrębniono główne obszary tematyczne cytowań.

Słowa kluczowe: umiędzynarodowienie czasopisma; badania naukoznawcze; analiza bibliometryczna; teoria zależności; logika deskrypcji

\section{The Analysis of the Level of Internalization of the Problems of the Science of Science Quarterly in the Context of World Studies on Science and Higher Education}

\footnotetext{
Abstract. The purpose of this article is to characterize the internationalization of the journal of Zagadnienia Naukoznawstwa (Problems of the Science of Science Quarterly). The main reference of this analysis is the Scopus database, which played a key role in the recent categorization of Polish and international scientific journals carried out by the Ministry of Science and Higher Education. This study uses some elements of my earlier works (Kawalec 2017, 2019). In the analysis of the citation of the journal Zagadnienia Naukoznawstwa, special attention was paid to sources that have high citation in the Scopus database, and the main thematic areas of citation were identified.

Keywords: internationalization of a journal; science of science; bibliometric analysis; dependence theory; logic of descriptions

* Dziękuję uczestnikom Posiedzenia Plenarnego Komitetu Naukoznawstwa, które odbyło się 23 listopada 2019 roku, za pomocne uwagi, a także dwóm anonimowym recenzentom za wnikliwe i szczegółowe komentarze, które pozwoliły usunąć usterki wcześniejszej wersji artykułu.
} 


\section{Wstęp}

Czasopismo Zagadnienia Naukoznawstwa jest wydawane przez Polską Akademię Nauk od 1965 roku i jest jednym z najstarszych pism naukoznawczych na świecie. W Polsce pierwszym pismem naukoznawczym był Organon, ukazujący się od 1936, a reaktywowany w $1964 \mathrm{roku}^{1}$. Natomiast zagranicznym najstarszym czasopismem, które miało duży wpływ na kształtowanie tematyki naukoznawczej, jest wydawana od 1962 roku Minerva. Współczesne międzynarodowe czasopisma naukoznawcze, których znaczenie jest nie do przecenienia, powstały w późniejszym okresie, np. Research Policy - 1971, Science Studies - 1971 (od 1975 jako Social Studies of Science), Science and Public Policy - 1974, czy Scientometrics - 1978 rok. W związku z tym zasadne jest pytanie o rolę, jaką odegrało czasopismo Zagadnienia Naukoznawstwa na forum międzynarodowym. Niniejszy artykuł jest przyczynkiem do udzielenia takiej odpowiedzi, która w pełnym wymiarze wymaga szczegółowej analizy zawartości czasopisma, jak też paralelnie ukazującej się w latach 1980-1990 jego wersji anglojęzycznej-Problems of the Science of Science Quarterly.

Jak wskazuje przeprowadzona wcześniej analiza dynamiki badań w obszarze science of science, kluczowe dla rozwoju tego obszaru badań były dwa okresy: początek lat 60. oraz lata 2010-2013 (Kawalec 2019). W rozwoju tego obszaru badań wyodrębnione zostały cztery zasadnicze okresy: humanistyczny (1930-1970), ideologiczno-polityczny (1970-1990), społeczno-ekonomiczny (1990-2010) oraz obliczeniowy (po 2010 roku). Jest to uszczegółowienie zaproponowanej wcześniej, na podstawie analizy cytowań artykułów publikowanych w Zagadnieniach Naukoznawstwa, periodyzacji, która zostanie także przyjęta na potrzeby niniejszego opracowania.

Pierwsze zwiastuny badań naukoznawczych pojawiły się równolegle w Polsce i USA jeszcze przed zakończeniem pierwszej wojny światowej. Z inicjatywy Stanisława Michalskiego Kasa im. Józefa Mianowskiego rozesłała wówczas ankietę do polskich uczonych w trzech zaborach w celu określenia najbardziej pilnych potrzeb nauki polskiej. Jej wyniki opublikowano w powołanym do życia w $1918 \mathrm{r}$. roczniku Nauka Polska. Jej potrzeby, organizacja i rozwój. Michalski podejmował systematyczne starania, by refleksja nad nauką i jej rozwojem w Polsce miała charakter naukowy, stąd zainicjowana przez niego działalność Koła Naukoznawczego (Kawalec 2018), zaangażowanie wybitnych uczonych, jak Florian Znaniecki (Znaniecki 1925) oraz Maria i Stanisław Ossowscy (Ossowska, Ossowski 1935, 1964), zainicjowanie wspomnianego czasopisma Organon, a także plany powoła-

\footnotetext{
1 Pierwsze prace naukoznawcze Znanieckiego i Ossowskich ukazały się w czasopiśmie Nauka Polska, publikowanym od 1918 roku przez Kasę im. Józefa Mianowskiego, głównie z myślą o bieżących potrzebach nauki. Po zawieszeniu wydawania go w 1947 zostało reaktywowane w 1992 roku.
} 
nia naukoznawczego instytutu badawczego w końcu lat 30., udaremnione niestety przez wybuch drugiej wojny światowej. Z kolei w USA, również w 1916 roku, rozpoczął działalność Research Information Service w ramach the National Research Council. Jednak wraz z zakończeniem wojny zasadniczo zmienił on profil swojej działalności.

Mimo to powszechnie uznaje się, że pierwszy okres w międzynarodowych badaniach naukoznawczych na ogół otwiera publikacja pracy Johna Bernala The Social Function of Science w 1939 roku (Bernal 1939). Roger Pielke, w 75 rocznicę ukazania się tej publikacji, podkreślił, że „Dla Bernala użyteczność była czymś więcej niż aspiracją: była głównym celem przedsięwzięcia naukowego i pożądanym celem wsparcia nauki przez państwo" (Pielke 2010, s. 427). Chris Freeman, założyciel ośrodka Science Policy Research Unit w Sussex, zwracał uwagę, że Bernal jako pierwszy oszacował wszystkie wydatki ze środków publicznych na naukę w Wielkiej Brytanii, jeszcze zanim stworzono system pozwalający na raportowanie danych, które miały służyć do pomiarów PKB. W tym czasie było to całkowicie nowatorskie podejście do zagadnień naukoznawczych i dopiero znacznie później, od lat 60., upowszechniło się ono na skalę międzynarodową, głównie za sprawą konferencji zorganizowanej przez OECD we włoskim Frascati. Publikacja książki Bernala może być uznana za moment przełomowy dla wyodrębnienia się naukoznawstwa (w sensie science of science), gdyż dokonała swego rodzaju krystalizacji wcześniejszych inicjatyw, np. the British Science Association w 1937 roku odbyło posiedzenie zatytułowane „Science and Social Welfare”, a the American Association for the Advancement of Science rok później wśród swoich celów wprost zawarło odniesienie do badania wpływu nauki na społeczeństwo. Książka Bernala okazała się kontrowersyjna nie tylko ze względu na porzucenie ideału naukowca jako akademika działającego $\mathrm{w}$ wieży z kości słoniowej na rzecz zaangażowania $\mathrm{w}$ rozwiązywanie problemów społecznych. Bardziej problematyczne okazało się jego przywiązanie do planowania centralnego, będące odzwierciedleniem jego zapatrywań ideologicznych. Bernal uważał Związek Radziecki za wzór organizacji nauki, czemu najbardziej dobitnie dał wyraz w sformułowaniu science is communism („nauka to komunizm”) (Pielke 2014, s. 427). Adwersarzem takich poglądów stał się Michael Polanyi, który w pierwszym tomie czasopisma Minerva opublikował swoją republikańską wizję autonomicznie uprawianej nauki w często przywoływanym artykule The Republic of Science: Its Political and Economic Theory (Polanyi 1962, 2000).

Lata 40. i 50. to intensywny okres kształtowania się czterech zasadniczych obszarów badań naukoznawczych (Kawalec 2018) w zakresie: ekonomii i polityki gospodarczej, naukometrii, socjologii oraz filozofii nauki. Ta ostatnia jednak ustępowała miejsca w dyskursie publicznym pozostałym obszarom, czego najbardziej symbolicznym wyrazem była aktywność the Harvard Science of Science Discussion Group w latach 1940-1941. Obok wybitnych naukowców uczestniczyło wielu 
znanych przedstawicieli empiryzmu logicznego, którzy z Europy wyemigrowali do Stanów Zjednoczonych. Jej pracami kierował zadeklarowany zwolennik operacjonizmu, Stanley S. Stevens (Stevens 1939), co znalazło swój wyraz w postulacie unaukowienia badań nad nauką i skierowania ich na tory naukowości, wyrażającej się ścisłymi pomiarami i obliczeniami.

Kluczową rolę na tym etapie kształtowania się naukoznawstwa odegrali doradcy prezydentów USA w czasie drugiej wojny światowej: Vannevar Bush oraz James Conant. Bush opublikował słynny raport Science: The Endless Frontier, w którym z pomocą znanego ekonomisty Paula Samuelsona sformułował klasyczną dziś argumentację na rzecz wiedzy naukowej - zwłaszcza w obszarze tzw. badań podstawowych - jako dobra publicznego, które wymaga interwencji państwa. Te idee znalazły później swoje rozwinięcie m.in. w modelach rozwoju gospodarczego Roberta Solowa, uwzględniających postęp techniczny jako jeden z trzech głównych czynników, oraz u Kennetha Arrowa, autora słynnego argumentu z porażki rynkowej, uzasadniającego interwencję państwa w wolny rynek w celu wprowadzenia skutecznych zachęt do generowania wiedzy naukowej (Kawalec 2018). Raport Busha ostatecznie doprowadził do utworzenia w 1951 roku nowej agencji w USA, National Science Foundation, której celem było finansowanie badań podstawowych ze środków publicznych.

Pracami Busha oraz jego futurystycznymi wizjami rozwoju nauki i społeczeństwa zainspirował się Eugene Garfield, który w 1955 roku stworzył - istniejący do dziś - the Institute for Scientific Information. Jego zadaniem miało być systematyczne gromadzenie danych o publikacjach naukowych, a następnie określanie ich wpływu (impact factor) i roli w rozwijaniu wiedzy naukowej. Autorem pierwszych prób wskazania pewnych regularności w rozwoju nauki na podstawie gromadzonych danych naukometrycznych był Derek John de Solla Price. Zwieńczeniem ponad 10 lat jego badań była opublikowana w 1961 roku monografia Science Since Babylon (de Solla Price 1975). Bardziej ścisłe powiązanie wczesnych prac naukometrycznych z bieżącą polityką gospodarczą dokonało się za sprawą publikacji przez OECD w 1962 roku Podręcznika Frascati, który był efektem wspomnianej wcześniej międzynarodowej konferencji, mającej m.in. na celu standaryzację pomiarów działalności naukowej i sprawozdawczości związanych z nią wskaźników.

Warto zwrócić uwagę na jeszcze jedną z ważnych publikacji, które ukazały się w przełomowych dla studiów naukoznawczych latach 60 . W okresie powojennym Conant, jako rektor Uniwersytetu Harvarda, rozpoczął realizację szeroko zakrojonego projektu upowszechnienia wiedzy naukowej. Do jego wykonania zatrudnił młodego asystenta - Thomasa Kuhna. Zainspirowany przez Conanta, m.in. analizowaniem aspektu dynamiki wiedzy naukowej oraz stosowanym przez niego określeniem schematu pojęciowego (Marcum 2015, s. 34), Kuhn opracował teorię paradygmatów, którą opublikował po raz pierwszy w 1962 roku (Kuhn 1962, 1970). 
Steven Fuller, zwróciwszy uwagę na rolę Conanta w jej zainspirowaniu, powstaniu i upowszechnieniu, podważa filozoficzne motywacje monografii Kuhna, która jako jedyna spośród koncepcji fillozoficznych znalazła szerszy oddźwięk w dyskursie publicznym o nauce, zdominowanym tematyką ekonomiczno-polityczną (Fuller 2000, s. 150).

Powyższy zarys kontekstu historycznego powstania pierwszych czasopism naukoznawczych, jak Minerva oraz Zagadnienia Naukoznawstwa, można zakończyć podkreśleniem specyfiki sytuacji politycznej czasów ich powstania. Pierwszym wydawcą czasopisma Minerva był the Congress for Cultural Freedom, organizacja finansowana przez wywiad amerykański w celu prowadzenia wojny ideowej ze Związkiem Radzieckim. Pierwszy redaktor tego czasopisma, Edward Shils, w kontekście tego sporu za główny obszar zainteresowań czasopisma uznał wolność akademicką, co pozwoliło mu na bliską współpracę z wybitnymi intelektualistami i uczonymi, m.in. z Polanyim. Czasopismo spotkało się z bardzo dobrym przyjęciem także poza środowiskiem naukowym, najpierw w Wielkiej Brytanii, a później w USA. W analogiczny sposób Zagadnienia Naukoznawstwa utworzyły wśród swoich autorów, a także czytelników, bardzo zróżnicowany tematycznie przekrój, co wyraźnie jest odzwierciedlone w międzynarodowym odbiorze tego czasopisma, jak pokazuję w dalszej części niniejszego tekstu.

\section{Analiza źródeł i dynamiki cytowań Zagadnień Naukoznawstwa w bazie Scopus}

Głównym materiałem do analiz w tej części jest baza danych, która powstała poprzez wyodrębnienie w bazie Scopus 85 źródeł cytujących artykuły opublikowane w czasopiśmie Zagadnienia Naukoznawstwa. Na razie jest to jedyna możliwość analizy obecności tego czasopisma w bazie Scopus, gdyż dopiero podejmuje ono starania o indeksowanie w tej bazie. Baza danych obejmuje łącznie lata 1974-2019 (stan na 15 października 2019 roku). Źródła niepowtarzające się to łącznie 61 tytułów, wśród których są przede wszystkim czasopisma naukowe (53), ale także publikacje pokonferencyjne (3) i monografie zbiorowe (5).

Dla czasopism indeksowanych w bazie Scopus wskaźnikiem, który najbardziej adekwatnie pozwala ocenić ich jakość, jest SJR (SCImago Journal Rank). Wartość tego wskaźnika jest uwarunkowana tym, czy cytowania pochodzą ze źródła, które samo jest wysoko cytowane, czy też nie (iteratywny algorytm dokonuje pomiaru eigenvalue centrality w odniesieniu do cytowań pomiędzy poszczególnymi źródłami w sieci). W tym przypadku więc sama liczba cytowań przypadających średnio na jeden opublikowany artykuł ma mniejsze znaczenie niż to, jaka jest ,jakość” tych cytowań, uwarunkowana wpływem danego czasopisma w całej sieci cytowań. 
W przypadku Zagadnień Naukoznawstwa dopóki to czasopismo nie jest indeksowane w sieci źródeł w bazie Scopus, wartość SJR nie jest zdefiniowana. Jednak pewnym predykatorem tej wartości jest jakość źródeł, które cytują to czasopismo w bazie Scopus. Odzwierciedleniem tej jakości poszczególnych źródeł jest ich pozycja - wskazywana jako jeden z czterech kwartyli SCImago - w danym obszarze tematycznym, do którego jest przypisane czasopismo.

Spośród 53 czasopism, które cytują artykuły opublikowane w Zagadnieniach Naukoznawstwa, blisko połowa, czyli 25, ma najwyższą (18 - kwartyl Q1) lub drugą (kwartyl Q2) kategorię w odnośnym obszarze tematycznym SCImago (tabela 1).

Tabela 1. Prestiżowe czasopisma naukoznawcze cytujące Zagadnienia Naukoznawstwa

\begin{tabular}{|c|c|c|}
\hline Źródło & Obszar tematyczny SCImago & SCImago Rank \\
\hline Acta Astronautica & Aerospace Engineering & Q1 \\
\hline Theory and Decision & Arts and Humanities (miscellaneous) & Q1 \\
\hline $\begin{array}{l}\text { European Educational Research } \\
\text { Journal }\end{array}$ & Education & Q1 \\
\hline Studies in Higher Education & Education & Q1 \\
\hline Science and Public Policy & $\begin{array}{l}\text { Geography, Planning and } \\
\text { Development }\end{array}$ & Q1 \\
\hline Studia Logica & History and Philosophy of Science & Q1 \\
\hline $\begin{array}{l}\text { Information Processing and } \\
\text { Management }\end{array}$ & Information Systems & Q1 \\
\hline Journal of Information Science & Library and Information Sciences & Q1 \\
\hline Scientometrics & Library and Information Sciences & Q1 \\
\hline $\begin{array}{l}\text { Technological Forecasting and Social } \\
\text { Change }\end{array}$ & $\begin{array}{l}\text { Management of Technology and } \\
\text { Innovation }\end{array}$ & Q1 \\
\hline $\begin{array}{l}\text { Archivum Immunologiae et Therapiae } \\
\text { Experimentalis }\end{array}$ & Medicine (miscellaneous) & Q1 \\
\hline $\begin{array}{l}\text { European Journal of Cardio-thoracic } \\
\text { Surgery }\end{array}$ & Medicine (miscellaneous) & Q1 \\
\hline Dialectica & Philosophy & Q1 \\
\hline Erkenntnis & Philosophy & Q1 \\
\hline Philosophy of the Social Sciences & Philosophy & Q1 \\
\hline Minerva & Social Sciences (miscellaneous) & Q1 \\
\hline Local Government Studies & Sociology and Political Science & Q1 \\
\hline European Review of History & History & Q2 \\
\hline Cybernetics and Systems & Information Systems & Q2 \\
\hline Dialogue & Philosophy & Q2 \\
\hline $\begin{array}{l}\text { Poznan' Studies in the Philosophy of } \\
\text { the Sciences and the Humanities }\end{array}$ & Philosophy & Q2 \\
\hline Współczesna Onkologia & $\begin{array}{l}\text { Radiology, Nuclear Medicine and } \\
\text { Imaging }\end{array}$ & Q2 \\
\hline
\end{tabular}




\begin{tabular}{|l|l|c|}
\hline \multicolumn{1}{|c|}{ Źródło } & \multicolumn{1}{|c|}{ Obszar tematyczny SCImago } & SCImago Rank \\
\hline Social Science Information & Social Sciences (miscellaneous) & Q2 \\
\hline $\begin{array}{l}\text { Annals of Agricultural and } \\
\text { Environmental Medicine }\end{array}$ & Waste Management and Disposal & Q2 \\
\hline
\end{tabular}

Warto przy tym zwrócić uwagę na dwie obserwacje. Po pierwsze, jak wspomniałem w poprzednim punkcie, pierwsze czasopisma naukoznawcze, które powstawały w latach 60 ., cechuje szerokie zaangażowanie specjalistów reprezentujących różne dyscypliny naukowe. To zróżnicowanie nadal jest jednym z wyróżników Zagadnień Naukoznawstwa. Po wyeliminowaniu powtórzeń oraz przy założeniu, że każde z czasopism przypisane zostało jednemu obszarowi tematycznemu, w którym otrzymało najwyższy ranking SCImago, otrzymujemy następującą listę obszarów tematycznych: Aerospace Engineering; Arts and Humanities (miscellaneous); Education; Geography, Planning and Development; History; History and Philosophy of Science; Information Systems; Library and Information Sciences; Management of Technology and Innovation; Medicine (miscellaneous); Philosophy; Radiology; Nuclear Medicine and Imaging; Social Sciences (miscellaneous); Sociology and Political Science; Waste Management and Disposal.

Lista ta jest pełnym przekrojem dziedzin, które są wyróżnione w polskich systemach porządkowania dyscyplin naukowych: od nauk humanistycznych przez nauki społeczne, nauki o życiu, nauki ścisłe i techniczne, nauki o ziemi po nauki inżynieryjne.

Druga obserwacja dotyczy obecności na liście źródeł kluczowych czasopism światowych zajmujących się tematyką naukoznawczą. Wśród nich jest wspomniane wcześniej, najstarsze i pokrewne tematycznie czasopismo Minerva. Jest na niej także jedno z najstarszych czasopism zajmujących się historią i filozofią nauki - Erkenntnis, a także najbardziej prestiżowe czasopisma poruszające tematykę z zakresu polityki naukowej - Science and Public Policy, szkolnictwa wyższego - Studies in Higher Education, informacji naukowej - Journal of Information Science, oraz problematyki naukometrycznej - Scientometrics.

Biorąc pod uwagę, że wśród cytowanych tekstów zdecydowaną przewagę mają teksty najnowsze (opublikowane od 2010 roku - łącznie 53, co stanowi 62\%), z całą pewnością można uznać, że Zagadnienia Naukoznawstwa są czasopismem rozpoznawalnym na arenie międzynarodowej, oddziałującym na najważniejsze pisma naukoznawcze na świecie.

Pewnym zobrazowaniem tego wpływu jest analiza cytowań artykułów z Zagadnień Naukoznawstwa na tle innych kluczowych czasopism w obszarze naukoznawstwa. Takiej analizy dokonałem dla artykułów (wraz z pełną listą zawartych w nich cytowań) dotyczących tematyki naukoznawstwa. W tym przypadku Zagadnienia Naukoznawstwa w latach 1988-2003 były jednym z pięciu najbardziej znaczących 
źródeł tematyki naukoznawczej wśród czasopism cytowanych przez źródła indeksowane w bazie Scopus.

Rysunek 1. Dynamika cytowań czasopism naukoznawczych w bazie Scopus (1939-2019)

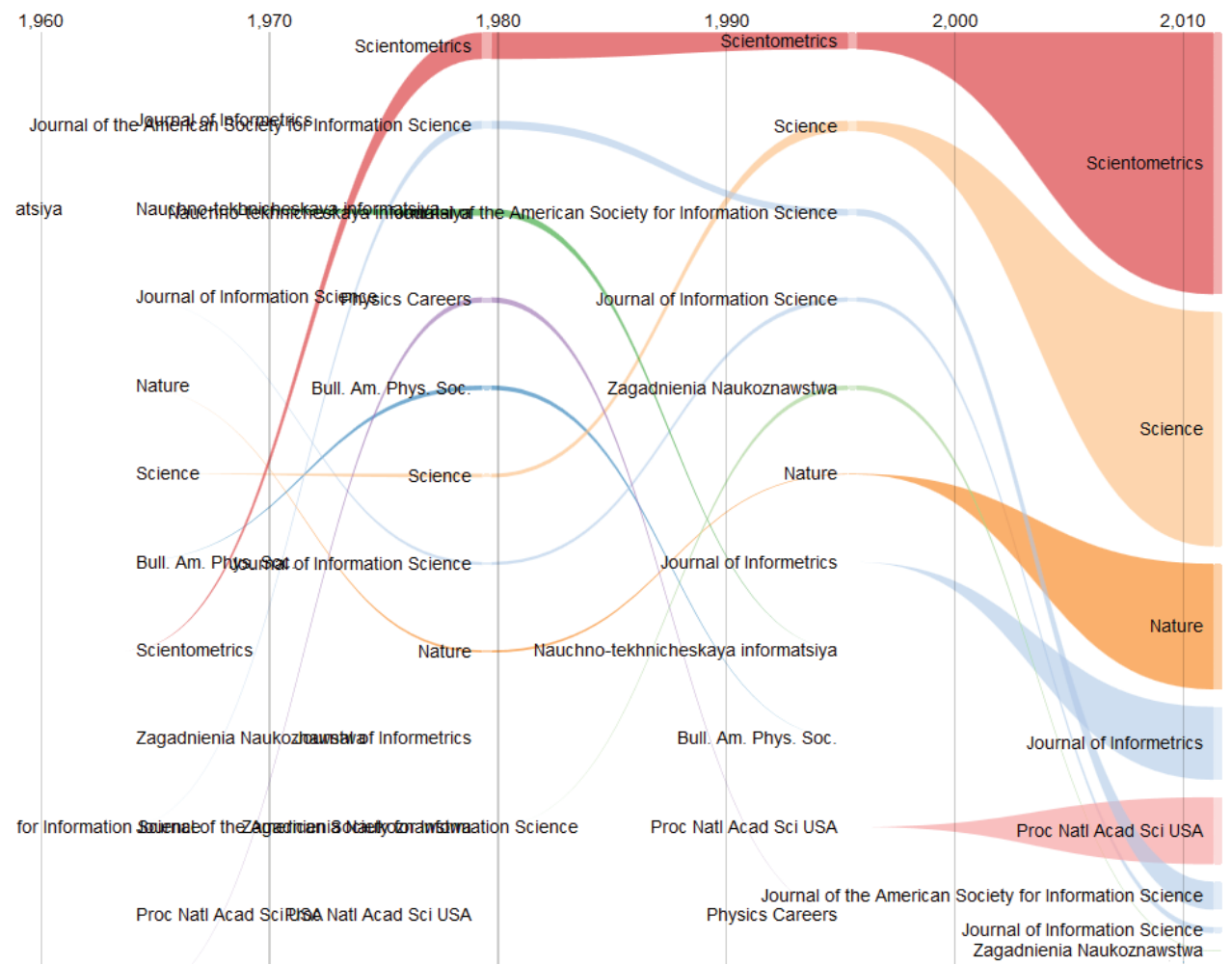

Źródło: analiza bazy danych artykułów wraz z cytowaniami, które w bazie Scopus są identyfikowane w wyszukiwaniu (tytuł, abstrakt, słowa kluczowe) przez frazę science of science. Dostęp: 3.10.2019 r.

Interpretacja wykresu przedstawionego na rysunku 1 wymaga uwzględnienia dwóch istotnych faktów. Po pierwsze, lata 1988-2003 były czasem, gdy w literaturze naukoznawczej toczyła się intensywna dyskusja o konstruktywizmie społecznym, określana niekiedy mianem „wojen naukowych” (science wars). Obszarem tematycznym identyfikującym tę debatę były (społeczne) „studia nad nauką" (science studies), podczas gdy tradycyjne podejście typu science of science, określone tak przez Stevensa, stało się wówczas na dłuższy czas zagadnieniem marginalnym, zwłaszcza w Stanach Zjednoczonych. Po drugie, Zagadnienia Naukoznawstwa jako czasopismo, które nie jest indeksowane w bazie Scopus, nie wskazują cytowań występujących w publikowanych w nim artykułach. Ponadto ze 
względu na to, że jest to czasopismo publikujące głównie w języku polskim, obraz cytowań jest dość istotnie niepełny, biorąc pod uwagę brak indeksowania tej bazie pozostałych polskojęzycznych czasopism naukoznawczych, w których są odwołania do Zagadnień Naukoznawstwa.

Rysunek 2. Główny komponent w sieci współautorów wg kraju afiliacji (8 z 12)

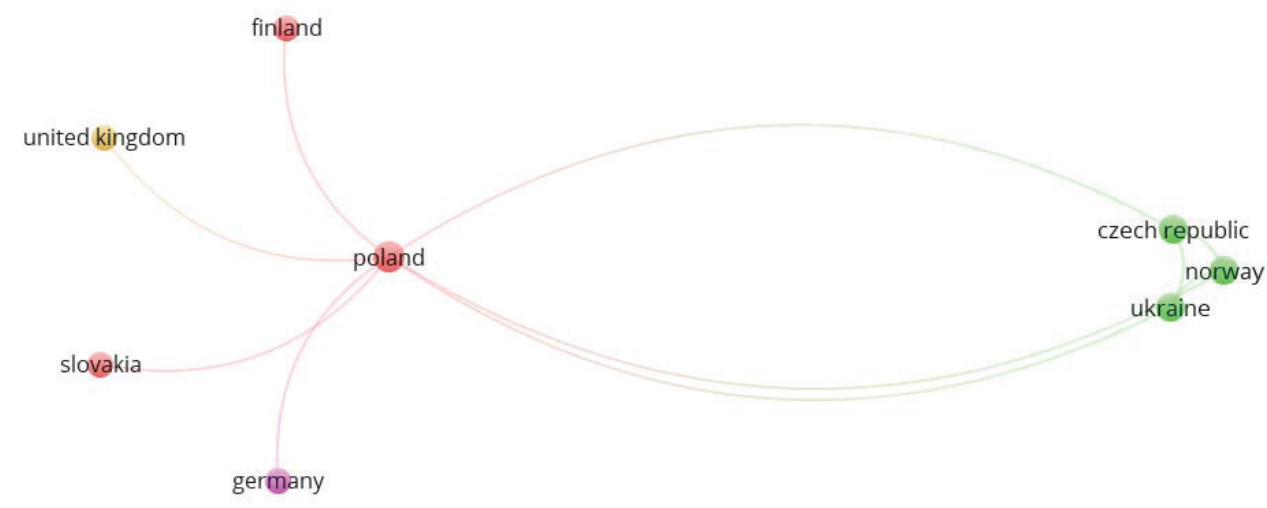

Źródło: analiza bazy danych artykułów wraz z cytowaniami, które w bazie Scopus są identyfikowane w wyszukiwaniu (tytuł, abstrakt, słowa kluczowe) przez frazę science of science. Dostęp: 3.10.2019 r.

Wykres obrazuje powiązania między krajami afiliacji współautorów tekstów (grupowanie przestrzenne z uwagi na częstość współautorstwa). Przedstawiony główny komponent tej sieci obejmuje osiem krajów powiązanych powyższą relacją z ogólnej liczby 12 (pominięte zostały kraje, które nie były powiązane z pozostałymi w ramach tej samej sieci). 
Rysunek 3a-c. Grupy źródeł

a

eur j cardiotbareac. \$45Eoryk ustroju polski,' przeglad history

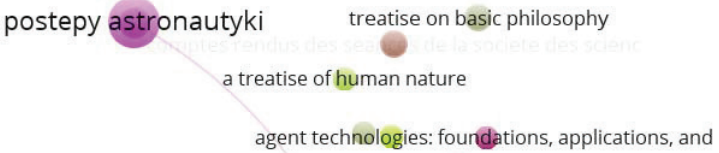

long range planning american political science review

sovetskoe gosudarstvo i pravo 


\section{systems research}

systems research and behavioral science ieee transactions on systems, man, and
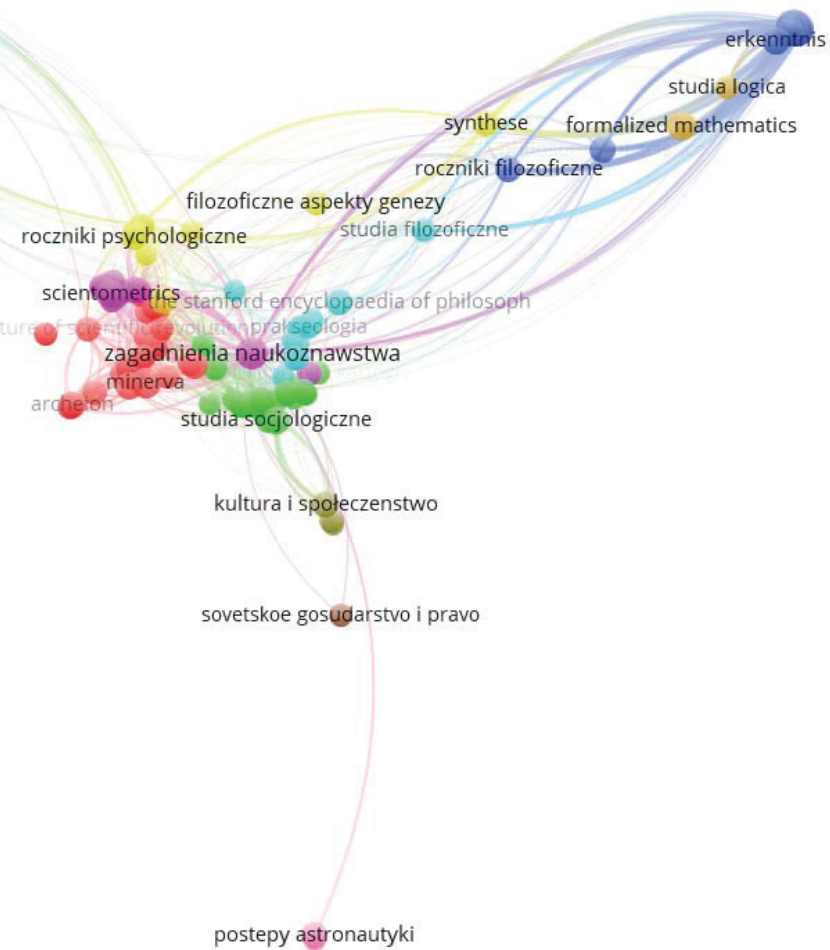

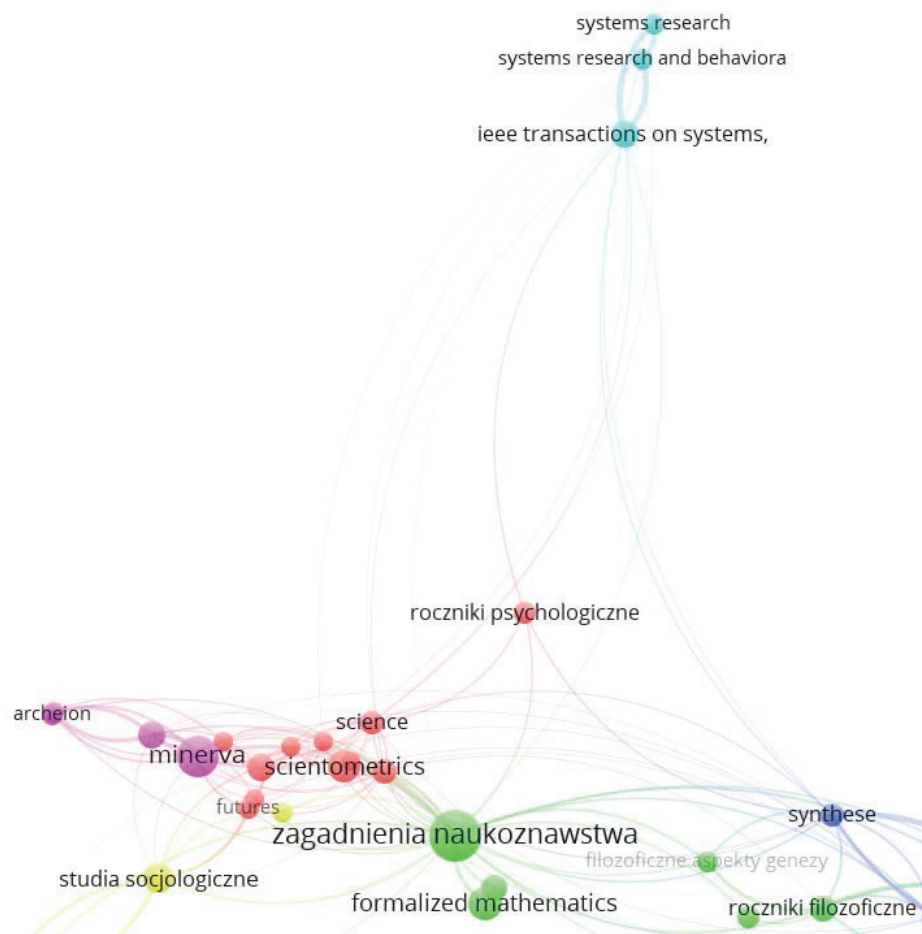

kultura i społeczenstwo

Źródło: analiza VoS z uwzględnieniem: a) wszystkich źródeł (3332); b) 5\% (149) źródeł (minimum 3 cytowania w bazie danych); c) 1\% (33) źródeł (minimum 8 cytowań w bazie danych).

\section{Przekrój tematyczny cytowanych prac}

Istotnym ograniczeniem przy dokonywaniu przeglądu tematycznego artykułów publikowanych w Zagadnieniach Naukoznawstwa, a cytowanych w bazie Scopus, jest fakt, że na 85 prac, które zawierają takie cytaty, tylko 47 (55\% cytowanych i mniej niż 5\% ogólnej liczby artykułów opublikowanych w Zagadnieniach Naukoznawstwa) ma pełniejsze metadane, uwzględniające słowa kluczowe, w tym podawane przez autorów tekstów w języku angielskim (Author keywords). Jest to dość istotna niekompletność, zwłaszcza gdy wziąć pod uwagę, że zdecydowana większość $\mathrm{z}$ tych źródeł, jak wspomniałem w poprzednim punkcie, to artykuły naukowe (53 z 85 prac). Związany z tym ograniczeniem jest również fakt, że autorskie słowa kluczowe, na podstawie których przeprowadziłem poniższą analizę, występują w nowszych tekstach, obejmujących lata 2006-2019. Łącznie więc 
w analizie uwzględnionych zostało 246 autorskich słów kluczowych w 47 artykułach (średnio ok. pięć słów kluczowych na artykuł).

Automatyczna analiza zgrupowań słów kluczowych z uwagi na ich współwystępowanie (co-occurrence), przeprowadzona za pomocą programu VoS, wyodrębniła 35 obszarów tematycznych. Największy komponent w tym zestawieniu obejmował 39 powiązanych ze sobą słów kluczowych, co stanowi ok. 16\% ogólnej liczby. Wskazuje to na duże rozproszenie tematyczne i brak powiązań między poszczególnymi obszarami tematycznymi (rysunek 4).

Rysunek 4. Grupy tematyczne wśród źródeł cytujących artykuły z Zagadnień Naukoznawstwa: a) analiza zagęszczenia związków tematycznych słów kluczowych; b) analiza nakładkowa dynamiki grup tematycznych w latach 2006-2019

a

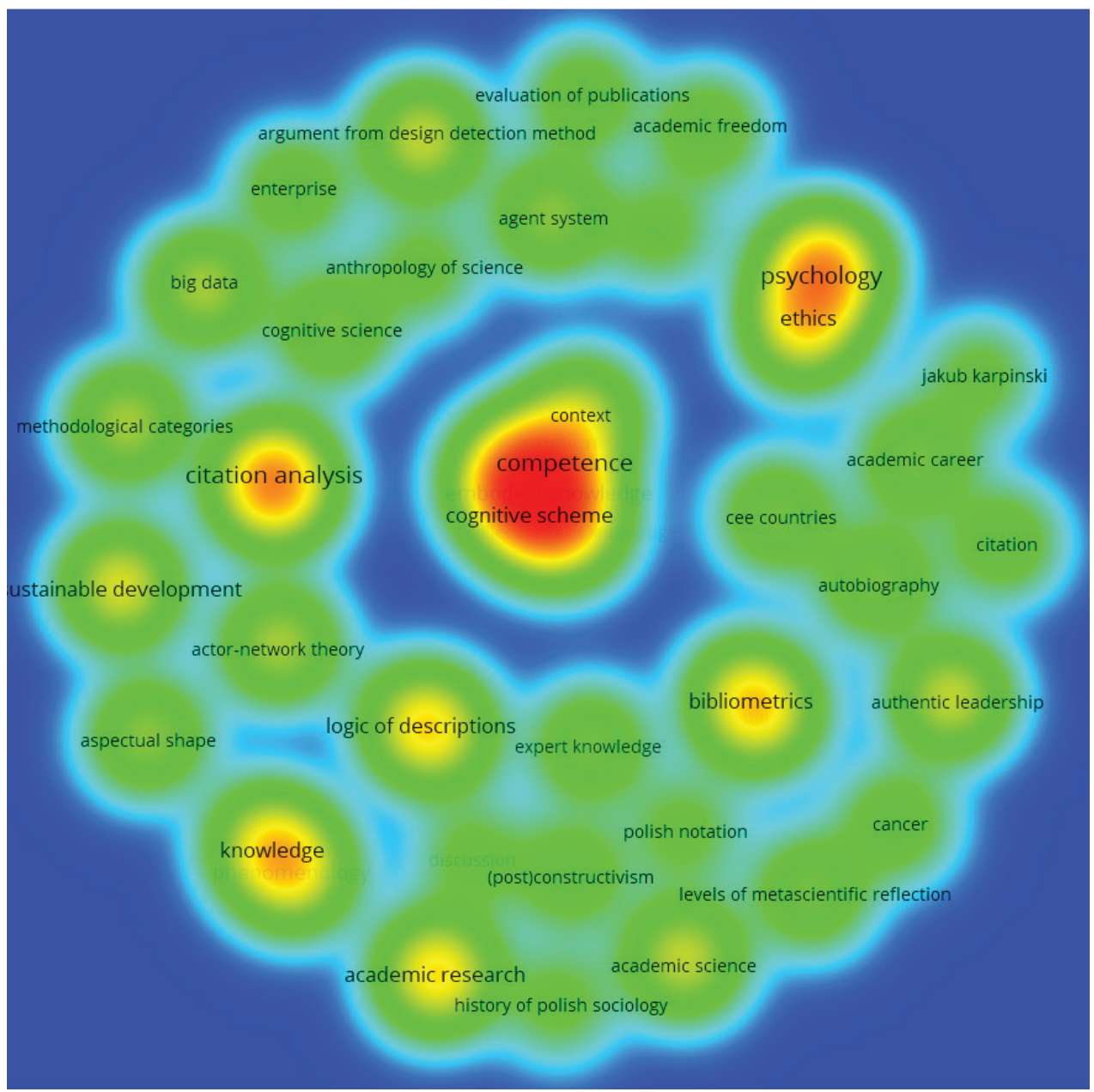


b

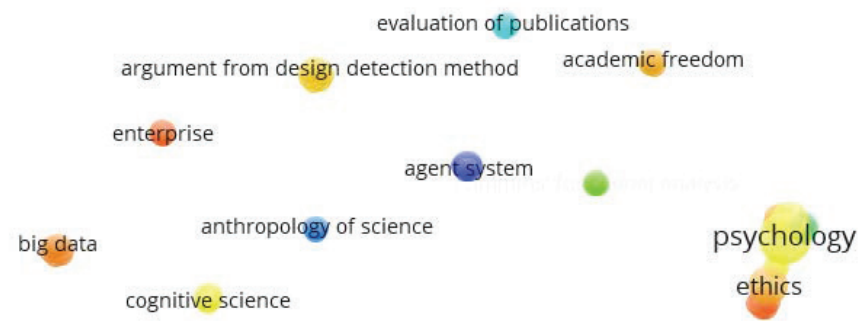

jakub karpinski

2thodological categories
citation analysis

ainable development

actor-network theory

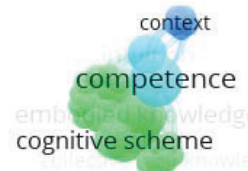

cognitive scheme

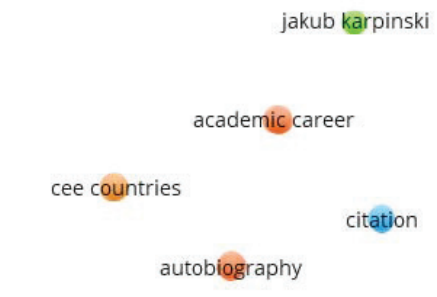
bibliometrics logic of descriptions expert knowledge

aspectual shape authentic leadership

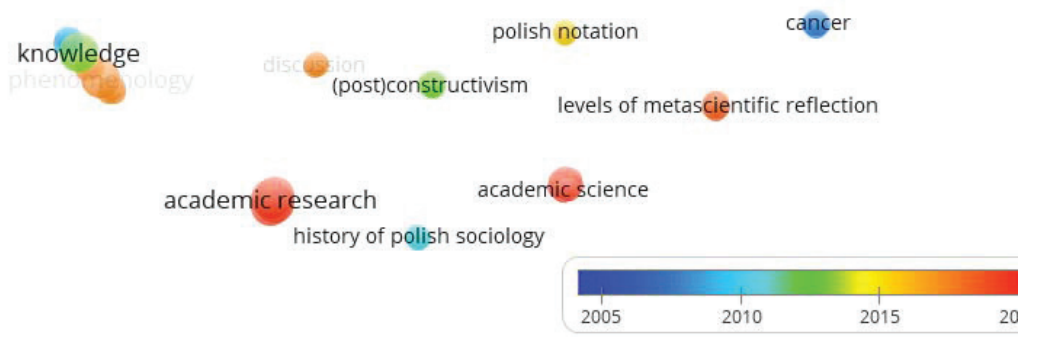

Źródło: analiza VoS z uwzględnieniem: a) wszystkich źródeł (3332); b) 5\% (149) źródeł (minimum 3 cytowania w bazie danych); c) 1\% (33) źródeł (minimum 8 cytowań w bazie danych).

Można $\mathrm{z}$ jednej strony to rozproszenie interpretować jako odzwierciedlenie interdyscyplinarności badań prowadzonych w ramach naukoznawstwa. Taka interpretacja, jak będzie to bardziej szczegółowo pokazane w dalszej części tego punktu, znajduje swoje potwierdzenie w korespondencji wyodrębnionych obszarów tematycznych z głównymi obszarami badań, jakie reprezentowane są w ramach sekcji tematycznych Komitetu Naukoznawstwa Polskiej Akademii Nauk, a także tematyką pokrewną. 
Z drugiej strony tak duże rozproszenie, a przede wszystkim brak zdecydowanie dominującego obszaru tematycznego, czyli najważniejszego komponentu, który obejmowałby blisko 50\% wszystkich słów kluczowych, może wskazywać, że główny obszar tematyczny oddziaływania Zagadnień Naukoznawstwa na skalę międzynarodową dopiero się kształtuje lub zmienia. Bardziej prawdopodobne wydaje się to drugie, jeśli odnieść się do analogicznego czasopisma, wspomnianego w pierwszym punkcie, a mianowicie Minervy. Przez pierwszych 20 lat działalności tego periodyku głównym obszarem tematycznym jego oddziaływania była wolność od wpływów ideologicznych w uprawianiu nauki. Dobitnym tego wyrazem jest fakt, że do dziś najczęściej cytowanym artykułem z tego czasopisma jest Michaela Polanyiego The Republic of Science: Its Political and Economic Theory z 1962 roku, który był polemiczną odpowiedzią na wizję Johna Bernala w monografii The Social Function of Science, opartej na ideologii komunistycznej. Pod wpływem zarówno czynników zewnętrznych (zmiana sytuacji polityczno-gospodarczej), jak i rozwoju teorii nauki, główny obszar tematyczny oddziaływania tego pisma uległ zdecydowanemu przekształceniu w kierunku dyskusji o społecznych studiach nad nauką, zwłaszcza związanych z nowym modelem produkcji wiedzy naukowej, czyli Mode-2.

Przegląd zakresu tematycznego prac indeksowanych w bazie Scopus, które przywołują artykuły publikowane w Zagadnieniach Naukoznawstwa, rozpocznę od głównego komponentu (rysunek 4), następnie przejdę do charakterystyki obszarów tematycznych, w oczywisty sposób korespondujących z głównymi dziedzinami badań naukoznawczych w Polsce, potem zaprezentuję obszary tematycznie im pokrewne, a na końcu krótko przedstawię pozostałe z nich.

Główny komponent związany jest przede wszystkim z tematyką wiedzy niejawnej, którą zainicjował Polanyi. Z uwagi na użycie takich kategorii jak „kompetencje” czy „,intuicja” do tej tematyki włączone zostały zagadnienia związane z posługiwaniem się językiem, zwłaszcza w teorii Noama Chomsky’ego (rysunek 5). 
Rysunek 5. Grupa tematyczna stanowiąca główny komponent

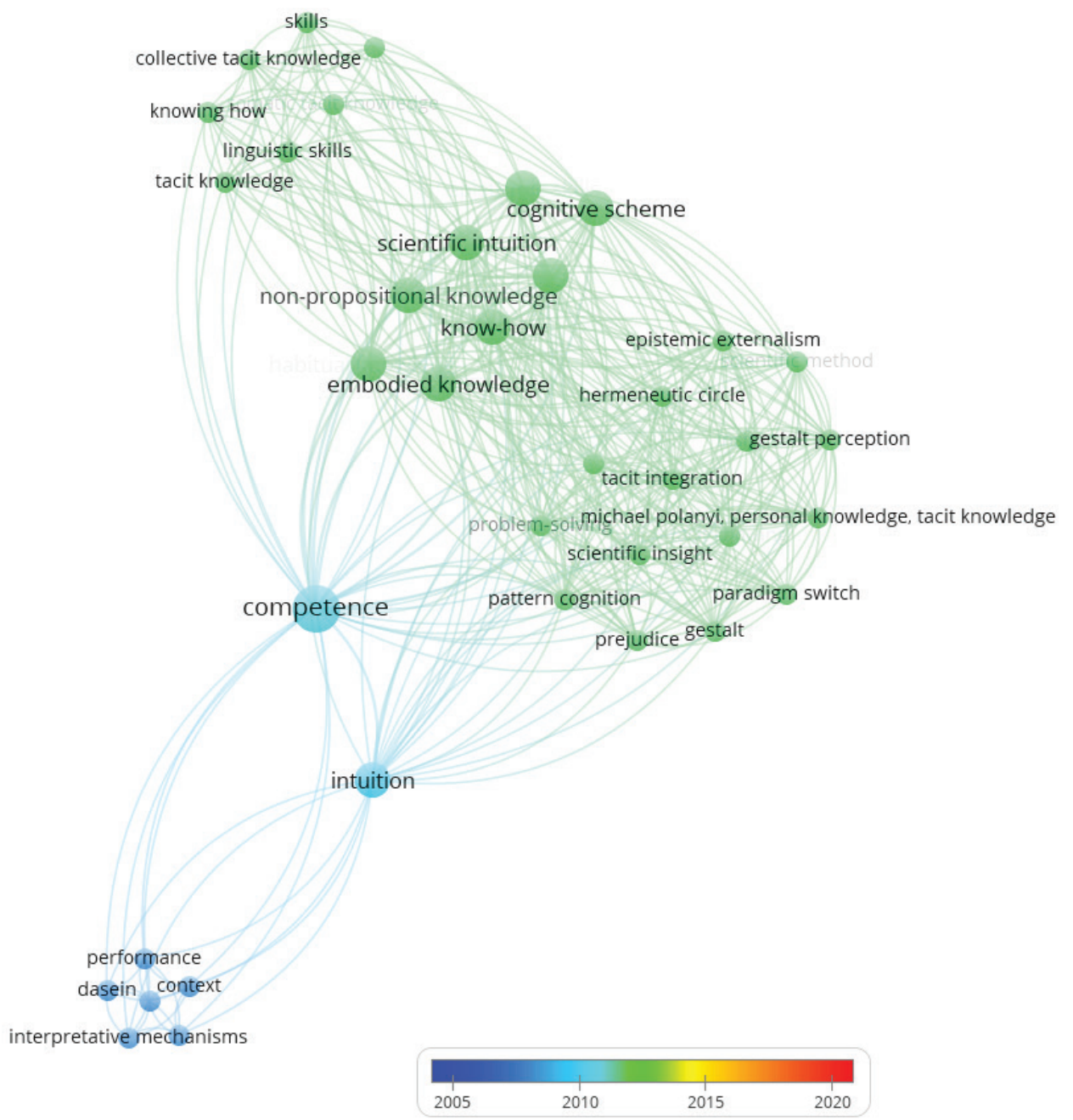

Źródło: analiza nakładkowa VoS. Główny komponent obejmuje 39 z 246 słów kluczowych (16\%).

Można więc uznać, że tylko częściowo ten główny komponent, wyodrębniony podczas automatycznej analizy, wprost odpowiada zainteresowaniom naukoznawczym, dla których zagadnienie wiedzy niejawnej jest istotne, choć nie pierwszorzędne. Zatem konstrukcja głównego komponentu nie odzwierciedla w pełni rzeczywistego wpływu Zagadnień Naukoznawstwa ani podejmowanych w tym czasopiśmie tematów naukoznawczych. 
Bardziej adekwatnym zobrazowaniem zarówno badań naukoznawczych publikowanych w tym czasopiśmie, jak i jego oddziaływania na inne źródła, są - jak sądzę - grupy tematyczne, które choć nie stanowią głównego komponentu, to wyraźnie wyodrębniają się w kilka kluczowych zagadnień. Mimo że prezentowane na rysunku 4 jako odrębne, wyraźnie zaznaczają swoją obecność zagadnienia związane $\mathrm{z}$ analizą naukometryczną, co ujawnia obecność dwóch ważnych grup tematycznych, a mianowicie citation analysis oraz bibliometrics (rysunek $6 \mathrm{a}-\mathrm{b})$.

Rysunek 6. Grupy tematyczne w obszarze badań naukometrycznych

a

development of geography and regional studies
googe scholar

citations

bibliometrics

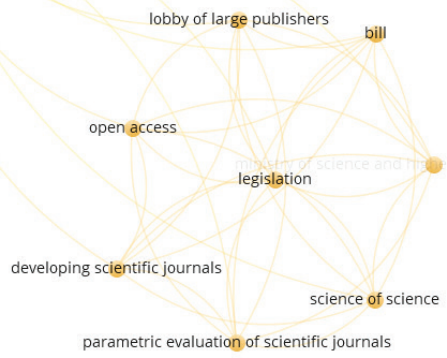

parametric evaluation of scientific journals 


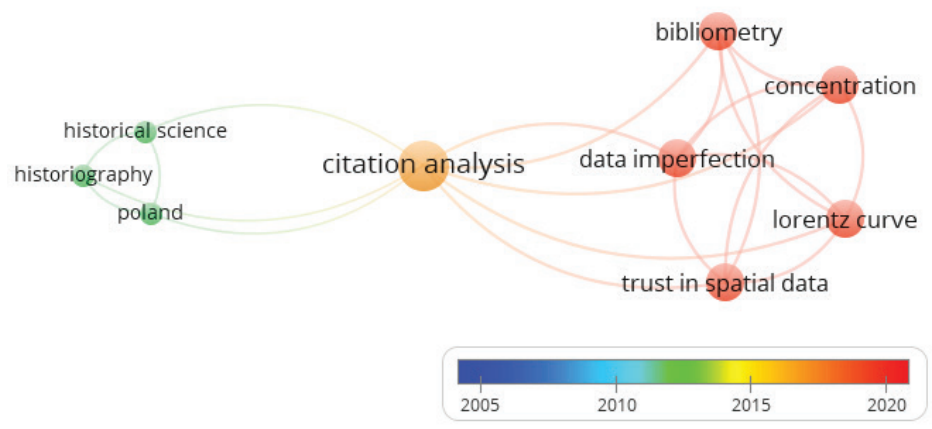

Źródło: analiza nakładkowa VoS. Panel: a) biliometrics, b) citation analysis.

Wśród wyróżników tych analiz można wskazać dwa elementy: próbę charakterystyki specyfiki cytowań w badaniach historycznych, a co za tym idzie - także swoistych wymogów wobec analiz naukometrycznych. Drugim aspektem jest odniesienie przestrzenne dla analizowanych danych, co stanowi jeden z ważnych nurtów w ramach współczesnej wizualnej analizy danych.

W ramach tradycyjnej problematyki metodologicznej mieści się grupa zagadnień dotyczących ogólnej metodologii nauk, w tym kwestie wyodrębnienia jednostki w metodologicznej analizie aspektu statycznego i dynamicznego nauki. W tym obszarze także podejmowane jest tradycyjne zagadnienie demarkacji, w tym przypadku ze szczególnym odniesieniem do dyskusji o inteligentnym projekcie.

Jeden z obszarów tematycznych podejmuje ważne i aktualne zagadnienie zarządzania badaniami naukowymi. Analiza ta dotyczy kontekstu samorządów lokalnych w krajach Europy Środkowo-Wschodniej i przeprowadzona jest na gruncie teorii zależności (dependency theory), zgodnie z którą wyodrębnione zostają grupy krajów centralnych, narzucających sposób prowadzenia badań i tematykę badawczą w Europie, oraz grupy peryferyjne, odgrywające rolę absorpcyjną i naśladowczą (rysunek 7). 
Rysunek 7. Grupa tematyczna - dependency theory

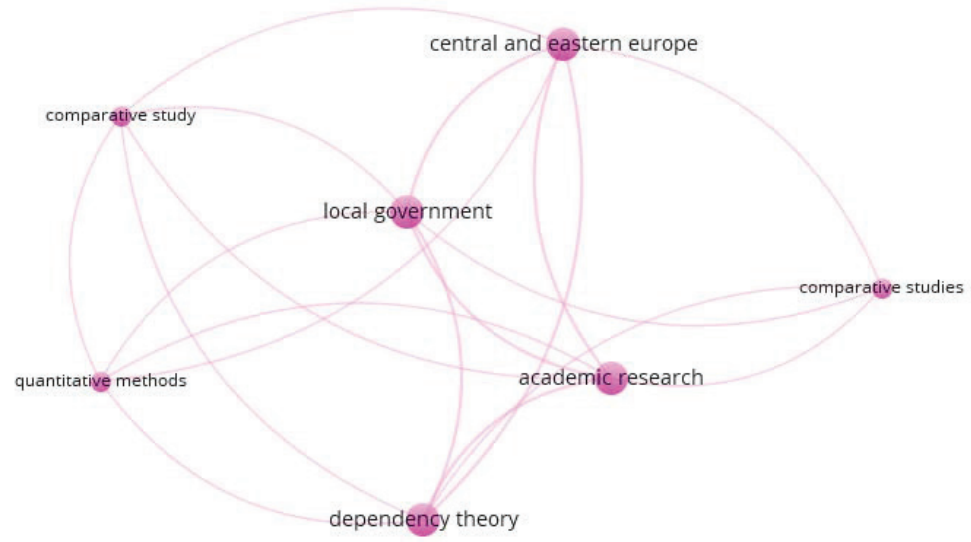

Źródło: analiza grup tematycznych VoS.

Niejako przedłużeniem tej refleksji są społeczne badania nad nauką, które identyfikują pewne istotne przemiany $\mathrm{w}$ badaniach społecznych. Jedną $\mathrm{z}$ nich są wyzwania ilościowej analizy danych, które ukierunkowują uwagę na nowy paradygmat „socjologii cyfrowej” (digital socjology). Inną jest rozwój nauk o poznaniu (cognitive science) oraz wprowadzania zmian technologicznych, modyfikujących naturalne zdolności człowieka (transhumanizm).

Inne pokrewne badaniom naukoznawczym rozważania reprezentuje obszar wskazany tu jako logic of descriptions. Ten nowy obszar badań w logice został zainicjowany pracą wybitnego polskiego logika, Andrzeja Grzegorczyka, opublikowaną w Zagadnieniach Naukoznawstwa w 2011 roku (Grzegorczyk 2011). Dynamikę rozwoju tematycznego tego obszaru prezentuje rysunek 8 . 
Rysunek 8. Grupa tematyczna - logic of descriptions

$$
\begin{gathered}
\text { equimeaning } \\
\text { descriptive equivalence } \\
\text { extensionality }
\end{gathered}
$$

non-fregean logic

equimeaning connective

non-classical propositional logic

logic of descriptions

equivalence connective

non-classical logic

paradoxes of implication

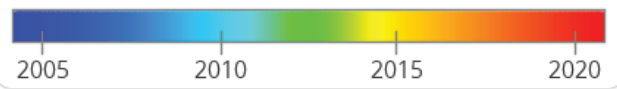

Źródło: analiza nakładkowa VoS.

Centralnym pojęciem dla naukoznawstwa jest kategoria nauki. W jednej z wyróżnionych w analizie VoS grupie odnosi się ona do szeroko zakrojonej tematyki. $\mathrm{Z}$ jednej strony jest to zagadnienie internacjonalizacji wiedzy naukowej, zwłaszcza w krajach Europy Środkowo-Wschodniej. Z drugiej natomiast - roli wiedzy w organizacjach, ale postrzeganej w perspektywie jakościowej (fenomenologia organizacji). Istotnym tematem, który nawiązuje do wcześniej wymienionej grupy społecznych studiów nad nauką, jest rola ekspertów naukowych w krajach demokratycznych.

Ostatnia grupa pokrewnych tematycznie badań dotyczy zagadnień zorientowanych przede wszystkim psychologicznie. Jednym z wyróżniających się tu tematów jest model transgresyjny człowieka, przy czym odniesiony jest on do zasad zrównoważonego rozwoju. Innym jest psychologia percepcji bólu i związku z jakością 
życia, jeszcze innym - refleksja nad umiędzynarodowieniem publikacji z zakresu psychologii uwzględniająca różnice między uwarunkowaniami w działalności ściśle badawczej a praktyką psychologiczną. Te obszary przybliżono na rysunku 9.

Rysunek 9. Obszar tematyczny - psychology

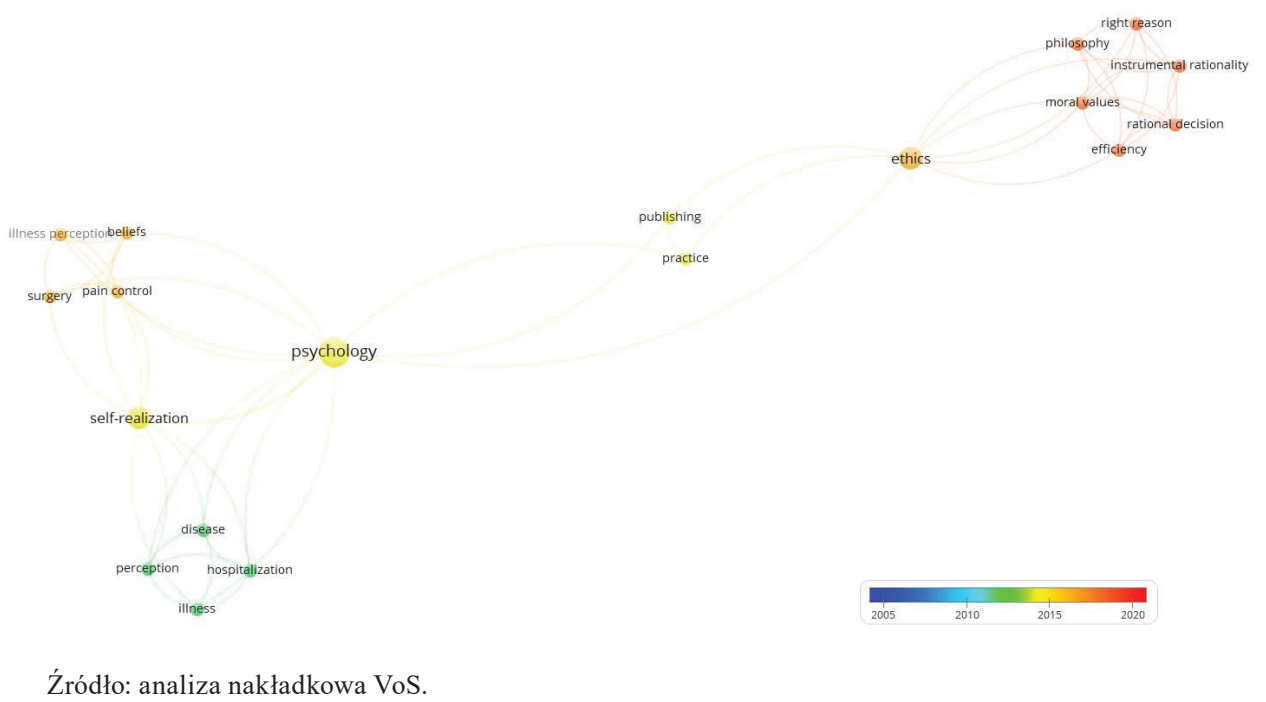

\section{Zakończenie}

W podsumowaniu warto zwrócić uwagę na istotne ograniczenia przeprowadzonej analizy. Baza Scopus bardzo fragmentarycznie odnotowuje cytowania polskojęzycznych wydań Zagadnień Naukoznawstwa (mniej niż 5\% ogólnej liczby artykułów, które ukazały się od początku istnienia czasopisma), w ogóle zaś nie odnotowuje cytowań wersji anglojęzycznej, która ukazywała się w latach 1980-1990, głównie z inicjatywy Wojciecha Gasparskiego. W związku z tym brak jednoznacznego określenia głównego obszaru tematycznego (,głównego komponentu" w analizie autorskich słów kluczowych) należy w dużej mierze upatrywać właśnie w braku danych. Ponadto zaskakuje dość istotny niedostatek metadanych, które dostępne są tylko dla 55\% dokumentów cytujących artykuły z Zagadnień Naukoznawstwa. Stąd niekompletność i rozproszenie poszczególnych grup tematycznych.

Warto na zakończenie podkreślić, że - mimo tych ograniczeń w dostępności danych - Zagadnienia Naukoznawstwa są wyraźnie obecne na forum międzynarodowym. Świadczą o tym przede wszystkim: a) cytowania przez najbardziej 
prestiżowe czasopisma naukowe, b) cytowania aktualnie publikowanych tekstów (lata 2006-2019), c) cytowania tych artykułów Zagadnień Naukoznawstwa, które podejmują bieżące problemy naukoznawcze, jak analiza cytowań czy teoria zależności, oraz d) oddziaływanie na pokrewne obszary tematyczne, stanowiące - jak w przypadku logiki deskrypcji - źródłową inspirację dla rozwijanej problematyki.

\section{Bibliografia}

Bernal J. D., 1939, The Social Function of Science, London: Routledge.

Fuller S., 2000, Thomas Kuhn: A Philosophical History for Our Times, Chicago: University of Chicago Press.

Grzegorczyk A., 2011, „Filozofia logiki i formalna logika niesymplifikacyjna”, Zagadnienia Naukoznawstwa 47(4): 445-450.

Kawalec P., 2017, „Wizualizacja publikacji naukoznawczych na przykładzie wybranych artykułów", Zagadnienia Naukoznawstwa 53(4): 373-388.

Kawalec P., 2018, "Philosophical Perspectives: The Science of Science - From Inception to Maturity”, w: F. Cain, B. Kleeberg (ed.), A New Organon: Science Studies in Interwar Poland, Tübingen: Mohr Siebeck, s. 521-535.

Kawalec P., 2019, "The Science of Science - Some Recent Advances”, Ruch Filozoficzny 75(2): $33-57$.

Kawalec P., 2020, „Cognitive Dynamics of Research Routines: Case Study of MicroRNA”, w: R. Giovagnoli, R. Lowe (ed.), The Logic of Social Practices, Cham: Springer International, s. 133-152.

Kuhn T. S., 1962, The Structure of Scientific Revolutions, International Encyclopedia of Unified Science, Vol. 2, $1^{\text {st }}$ ed., Chicago: Chicago University Press.

Kuhn T. S., 1970, The Structure of Scientific Revolutions, $2^{\text {nd }}$ ed., Chicago: Chicago University Press.

Marcum J. A., 2015, Thomas Kuhn's Revolutions: A Historical and an Evolutionary Philosophy of Science?, London-New Dehli-New York-Sydney: Bloomsbury.

Ossowska M., Ossowski S., 1935, „Nauka o nauce”, Nauka Polska 20: 1-12 [angielskie tłumaczenie ukazało się w 1936 r. czasopiśmie Organon 1: 1-12, a w 1964 r. w londyńskiej Minervie 3(1): 72-82].

Pielke R., 2010, “In Retrospect: Science - The Endless Frontier”, Nature 466: 922-923.

Pielke R. Jr., 2014, “In Retrospect: The Social Function of Science”, Nature 507: 427-428.

Polanyi M., 1962, “The Republic of Science: Its Political and Economic Theory”, Minerva 1: 54-74.

Polanyi M., 2000, “The Republic of Science: Its Political and Economic Theory”, Minerva 38(1): $1-21$.

Price de Solla D. J., 1975, Science Since Babylon: Enlarged Edition (Paperback), New Haven: Yale University Press.

Znaniecki F., 1925, „Przedmiot i zadania nauki o wiedzy”, Nauka Polska 5: 1-78. 